\title{
Sustainable development of territories of traditional environmental management in the conditions of implementation of investment projects
}

\author{
M. B. Pavlova ${ }^{1, *}$, V. In. Mikhaylova ${ }^{2}$, M. S. Malysheva ${ }^{1}, I . V$. Samsonova ${ }^{1}$, and L. A. Semenova ${ }^{2}$ \\ ${ }^{1}$ Academy of Sciences of the Republic of Sakha (Yakutia), Yakutsk, Russian Federation \\ ${ }^{2}$ Northeast federal university it M. K. Ammosova; State Budgetary Institution Academy of Sciences of the Republic of Sakha (Yakutia)
}

\begin{abstract}
Article is devoted to features of sustainable development of territories of traditional environmental management in the conditions of implementation of investment projects in South Yakutia. The main objective of a research consists in revealing features of sustainable development of the territory of traditional environmental management on the basis of interaction of three sectors of economy. The methodology of a research considers specific internal factors of social and economic development of settlements, a cycle of development of investment projects and gives an idea of economy of northern territories as unity of three sectors - traditional, industrial and state. Methods of the studying and the analysis of statistical documentation included in observations, poll are applied. The principles of sustainable development of territories of traditional environmental management at implementation of investment projects are specified.
\end{abstract}

\section{Introduction}

Stability is property of dynamically developing system which belongs to the environment capable to resist at external influences without changes of basic parameters of activity of local community.

The purpose of this article to reveal features of sustainable development of the territory of traditional environmental management on the basis of interaction of three sectors of economy on the example of South Yakutia.

Object of a research of this article are territories of traditional environmental management. An object of research - detection of features of sustainable development of territories of traditional environmental management of South Yakutia.

The term "sustainable development" was introduced by scientific community the Roman club in the report "Growth limits" (1972) for the first time. The idea of transition of a civilization from proliferation to qualitative established "a new world economic order". The essence of the concept of sustainable development is given in the report "to the commission Brundtland" (1987) in which, was considered that such development, satisfies requirements and does not threaten a possibility of their satisfaction for future generations [12].

Since then the term underwent sufficient evolution and gained semantic value depending on scope of application and those problems which are submitted for discussion. In the International congress in Rio de Janeiro (1992) practical steps as the general scheme of behavior of people in "the planetary scale" were planned.
In 2018 the Roman club submitted the anniversary report "to Come On! Capitalism, short-sightedness, the population and destruction of the planet" in which the concept of "the full world" offered by the American ecologist and the economist Herman Daley becomes a fulcrum. This concept suggests to seek for achievement of balance in all spheres of activity of the person [5].

Sustainable development of the territory of traditional environmental management in the conditions of the North assumes the accounting of internal factors of social and economic development of settlements and idea of North economy as unity of three sectors traditional, industrial and state.

The idea of three-sector model of the Arctic economy for the first time is stated abroad by the American economist Li Haski, in domestic science Zamyatina N. $\mathrm{Yu}$ and Pilyasov A. N. are considered as his followers. They offered the concept of the complex theory of development of the Arctic and the North. In the conditions of implementation of investment projects the trekhsektornost is considered as feature of social and economic development of northern territories.

Development of the industry in the territory of the Republic of Sakha (Yakutia) happens against the background of an economic crisis, caused by intensive development of the Arctic and development of production of natural resources of the Far East. At the same time many mineral deposits, to some extent affect territories of traditional environmental management (further - TTP). For protection of interests and rights, preservations of the primordial habitat of indigenous ethnic groups are formed and legislatively territories of

* Corresponding author: mpavlova@list.ru 
traditional environmental management where economic activity is limited [15] are fixed.

According to the Federal law of 07.05.2001 "About territories of traditional environmental management of indigenous ethnic groups of the North, Siberia and the Far East of the Russian Federation" formation of territories of traditional environmental management is carried out No. 49-FZ for the purpose of a possibility of preservation of places of traditional economic activity of indigenous ethnic groups. In similar territories various zones are created and the special legal regime is introduced. Rejection of a part of the territory in the form of rent of the land plots or an easement under industrial development happens according to the Federal law of 30.04.1999 No. 82-FZ "About guarantees of the rights of indigenous ethnic groups of the Russian Federation". Withdrawal of territories of cervine pastures and hunting grounds happens by compensation of losses from traditional environmental management of tribal communities of indigenous ethnic groups.

Decisions of local governments formed 62 territories of traditional environmental management of local value, including 9 in borders of municipal districts, 50 municipalities, 2 - intermunicipal level and 1 in the territory of nomadic tribal community. According to the resolution of the government of the Republic of Sakha (Yakutia) of 13.02.2019 No. 23 the Ministry of development of the Arctic and affairs of peoples of the North of the Republic of Sakha (Yakutia) is authorized body concerning formation of territories of traditional environmental management of the small people of regional value and keeps the register.

Development of fields happens on territories of traditional environmental management unevenly. Life cycle of the investment project has four main phases: preinvestment, investment, operational and liquidating. The conducted researches in the territory of South Yakutia from 2017 to 2019 show on a possibility of influence of municipal bodies, the population only at a design stage of an industrial facility. In an investment stage, in communication by involvement of the enterprise of considerable funds for construction of industrial facilities and their infrastructure influence of local authorities and the population decreases. In the period of an operational phase the main impact on the industrial companies can be exerted violation of the environment by them at which there is growth of conflict situations to local community which demands settlement.

\section{Methods}

We considered the different types of traditional activity inherent in tribal communities of areas of South Yakutia on the basis of studying and the analysis of statistical documentation, methods of the included observation, poll (an interview, questioning, focus group).

Field researches were conducted in the villages of Khatystyr of the Aldan district, Iyengr of Neryungrinsky district, and also Koudou-Cuel of the Olyokma district of the Republic of Sakha (Yakutia) in March, October and
November, 2019. Thirty four informants participated in an interview. Selection of a qualitative research entered: deputy heads of municipalities, chairmen and members of tribal communities, directors of the municipal enterprises, representatives of indigenous ethnic groups, experts in the field of agriculture, educations, health care, cultures and representatives of public organizations.

Questioning was carried out to the village of Iyengr. In total $5,4 \%$ of adult population are interviewed. Average age of respondents made 43 years. $83.6 \%$ Evenks took part in the survey, Russians $3.6 \%$ and $12.8 \%$ did not indicate their nationality.

Among respondents answers of those who since the birth lived in Iyengr - $72,7 \%$ and were engaged in traditional kinds of activity - 97,7\%, including reindeer breeding $-26,2 \%$, in hunting $-28,6 \%$, fishery $-23,8 \%$, fur farming $-2,4 \%$, collecting $-16,7 \%$ prevailed.

In article representation of sustainable development of territories of traditional environmental management as the integration mechanism consisting of three elements of social and economic subsystems is given. The contracts and agreements concluded between communities, companies and local governments in the study areas were studied.

\section{Results}

The southern economic zone of Yakutia includes the Aldan, Neryungrinsky and Olyokma districts which occupies to $14 \%$ of the total area of the republic. Administrative-territorial division of the Southern economic zone is presented 40 municipalities, including: 3 municipal districts: Aldan, Neryungrinsky and Olyokma, 11 city and 26 rural settlements. In city settlements $85 \%$ of the population are concentrated. 34 settlements $42 \%$ of country people of the Southern zone lived in them belong to remote, almost all of them are in the Olyokma district. Nine settlements belong to places of compact accommodation of indigenous ethnic groups.

We suggest to consider stability of the territory of traditional environmental management from the point of view of three sectoral model. Integration communications of elements of model are formed at implementation of investment projects. These elements are designated as sectors, and defined as traditional, state and industrial.

Traditional sector. Zone features and conditions of the Aldan and Neryungrinsky districts caused reindeerbreeding and hunting specialization of agriculture, in the Olyokma district - agricultural and cattle breeding, horse-breeding, reindeer breeding is also developed.

Year-round transport availability allowed to develop industrial poultry farming. In borders of the Southern economic zone about $5 \%$ of agricultural grounds and $9,4 \%$ of grassland of the general on the republic are concentrated. The share of gross output of agriculture makes $8,7 \%$ (2254 million rubles) of a gross product of the republic. The share of crop production - 10,9\%, livestock production $-7,7 \%$. The structure of a livestock of farm animals to the general livestock makes: cattle of- 
Table 1. THE LIST OF THE REALIZED INVESTMENT PROJECTS IN THE TERRITORY OF SOUTH YAKUTIA*.

\begin{tabular}{|l|l|c|c|}
\hline \multicolumn{1}{|c|}{ № } & \multicolumn{1}{|c|}{ Investment projects } & $\begin{array}{c}\text { Realization } \\
\text { period }\end{array}$ & $\begin{array}{c}\text { Volume of } \\
\text { investment }\end{array}$ \\
\hline 1. & Construction of coal mining and processing plant «Denisovsky» & $2012-2025$ & 32163,00 \\
\hline 2. & Construction of coal mining and processing plant «Inaglinsky» & $2008-2025$ & 32878,00 \\
\hline 3. & Development of the Elginsky coal field, Neryungrinsky district & $2008-2025$ & 173568,00 \\
\hline 4. & Construction of the Force of Siberia gas pipeline & $2014-2022$ & 670303,50 \\
\hline 5. & Construction of industrial complex for processing of hydrocarbons to Aldan» & $2015-2025$ & 130393,60 \\
\hline 6. & Development of the gold mining Gross mine, Neryungrinsky district & $2016-2018$ & 16250,00 \\
\hline 7. & $\begin{array}{l}\text { Construction of mining and processing plant Tarynnakhsky, development of the iron } \\
\text { ore field, Olyokma district }\end{array}$ & $2025-2028$ & 117877,00 \\
\hline 8. & Construction of Elkonsky mining and smelting plant, Aldan district & $2025-2035$ & 154357,90 \\
\hline 9. & $\begin{array}{l}\text { Construction of mining and processing plant Taiga , working off of the Taiga iron ore } \\
\text { field, Neryungrinsky district }\end{array}$ & $2015-2025$ & 95500,00 \\
\hline 10. & Completion of construction of a start-up complex Tommot-Yakutsk (Nizhny Bestyakh) & $2005-2017$ & 48687,07 \\
\hline 11. & $\begin{array}{l}\text { Completion of construction the site Berkakit - Tommot to norms of continuous } \\
\text { operation }\end{array}$ & $2017-2019$ & 7000,00 \\
\hline *The strategy of social and economic development of the Republic of Sakha (Yakutia) for the period till 2030 with definition of target vision till 2050 \\
\hline
\end{tabular}

$3,8 \%$, horses- 4,5 of $\%$, pig- 15,2 of $\%$, bird- 45,6 of $\%$, deer of $13,3 \%$. For the beginning of 2019 in the considered zone 32 economy, including 55 tribal communities are engaged in traditional economic activity. Communities participate in the solution of the general tasks of delivery to the market of production of traditional branches. As of January 01, 2019 the livestock of deer makes 19298 heads $(13,3 \%$ of the general livestock of the republic), of them in tribal communities - 6179 heads $(32 \%)$.

Hunting - one of priority types of traditional environmental management of indigenous ethnic groups of the North. Hunting grounds occupy about 40705 thousand hectares, i.e. $13,3 \%$ of the general territory of the republic. In total 10353 hunters are registered, 379 long-term licenses [12] are granted. The following types concern to hunting-trade animals: wolf, fox, squirrel, sable, ermine. In places of compact accommodation of indigenous people in 2018 it is prepared furs of 5872 pieces, including in the Aldan district - 2341 pieces., Olyokma - 1194 pieces, Neryungrinsk - 2337 pieces. In these areas the main volumes of skins of sables in the republic are bought. Areas of compact accommodation of indigenous ethnic groups of the North traditionally come to the forefront in fur trade of the republic [8].

Public sector. An important role in economic development of South Yakutia is played by the transport availability providing a continuous reliable communication with other regions of the country and creating conditions for development of resources of a region makrorayon. The main advantageIn Neryungrinsky and Aldan districts is year-round functioning of the leading means of transport - railway, automobile and air that favourably distinguishes them from other areas of the republic. The transport system of the Olyokma district is developed poorly, the main transport arteries of the area are Lena River and regional Road "Umnas" which has no year-round journey.

Population for January 1, 2019 in a zone makes 136 546 people $(14,1 \%$ of population of the republic). The tendency to decrease in population - from 144,3 thousand people in 2013 to 136,5 thousand people in 2018 is traced, recession made 7,8 thousand people
$(5,4 \%)$ due to outflow of the population. On rate of a gain of the monetary income of the population (at the rate of the volume of social payments and the taxable monetary income per capita) the Southern zone for 20132018 advances by $31,6 \%$ average rates on the republic. Labor market in a zone is characterized by rather average level of unemployment, so the number of unoccupied citizens in the total number of the population averaged $1,4 \%$. In five years growth of a gross municipal product per capita is observed, so in 2018 this indicator made 880,3 thousand rubles, it is twice more than in 2013. Dynamics of investments into fixed capital by 2018 increased by 75299,6 million rubles.

Industrial sector. The zone is characterized as the center of industrial development of the republic - coal mining and gold. The main contribution to production of a gross municipal product of the Southern zone is made by mining, transport and construction. The total contribution of the Southern economic zone to VRP of the republic following the results of 2018 made 167886 million rubles or $18,3 \%$. In regions of the Southern zone of Yakutia the main investment projects are connected with development of a coal-mining complex, extraction of ores of minerals and transport infrastructure (tab. 1).

Today, there is an industrial development of projects of coal and gold mining, operation of the pipeline oilpipeline system "Eastern Siberia-Pacific Ocean", projects of construction of the Force of Siberia main gas pipeline, railway infrastructure are also carried out.

Influence of the industrial companies on social and economic development of the region makes an essential contribution to employment, development of social infrastructure and small business. The industrial companies bear social and ecological responsibility when signing agreements of cooperation on social and economic development. However, the companies on places do not seek for signing of agreements with the area, especially with municipalities not to bear responsibility for economic activity in territories of traditional environmental management.

By results of a field research by us it is revealed that in recent years the negative impact of the industrial sector on traditional - hunting, reindeer breeding, fishery, 


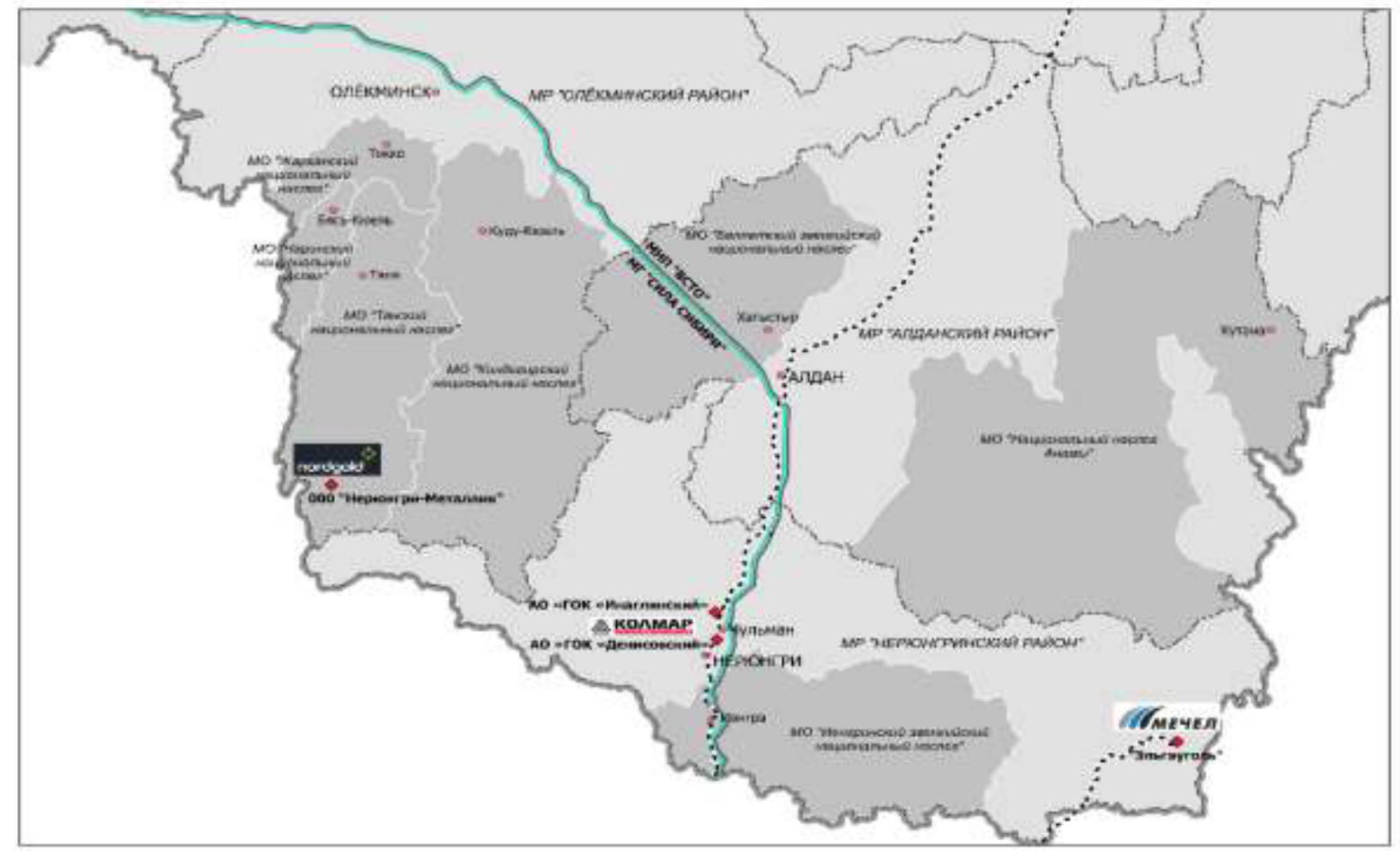

Fig. 1. Scheme of placement of investment projects in territories of traditional environmental management in South Yakutia.

collecting wild plants and subsidiary farm considerably increased. First of all, respondents note influence of such objects as gold mining, the gas pipeline and the oil pipeline. In the village of Iyengr among the industrial facilities which are negatively influencing maintaining traditional types specified gold mining artels (31\%), the oil pipeline (20\%), the gas pipeline (22\%), the Elginsky coal field (2\%). Besides, such industrial facilities as pits, scrap metal, boring were called, are expensive, etc.

Negative consequences of influence of the industry on traditional environmental management respondents called degradation of a natural landscape, reduction of a livestock of domestic deer, reduction of the territory of pastures, pollution of the soil and water, violation of migration of wild animals and ecological equilibrium.

In an interview of representatives of communities two types of the industrial companies which develop territories of nasleg - the large companies and small private enterprises are allocated. In their opinion, the large companies observe the legislation, carry out ethnological expertize, conclude agreements, pay the damages caused to indigenous ethnic groups of the North as a result of causing damage to their primordial habitat of economic activity and give target social support to municipalities within contracts of a charitable donation and social partnership: "The big companies all the same observe all this, it is easier to work with them. And here when the small enterprises, with them it is very heavy. There private traders, not the state enterprises therefore it is very heavy" (the director of municipal unitary enterprise, the village of Iyengr). On the contrary, the small enterprises often violate regulations, their economic activity makes considerable negative ecological impact on the environment and do not hold events for decrease in risk of emergence of negative ecological consequences of economic activity. respondents refer to gold mining artels of prospectors as small enterprises: "Gold prospectors they are seasonal. They to earn money here come, and behind the nature they do not look. Arrived, earned money, as they say, here left tracks, and left and, with money". Often happens so that prospecting artels work near reindeerbreeding herds: "And where my reindeer breeders, for some reason gold, gold prospectors too there is obligatory. gold diggers stand next to the reindeer herders ' camp. Across the road my tents stand, racross the road bulldozers work all day" (the chairman of a tribal community, the village of Khatystyr).

In all three distrcts the main problem note pollution of water resources. Especially the problem is particularly acute in Neryungrinsky district of the village of Iyengr. Residents of the village created Public ecological council which main objective interaction with the industrial companies for an ureuglirovaniye of problems with pollution of water and the soil. During the meeting, residents of the village described a situation with water as "awful", "deplorable": "We locals are most of all very strongly disturbed by prospecting artels. They, as a rule, on attention ecology do not turn at all". There is a typical example: "it at us "Titan Avtotreyd" they are developing a field near the Volkovsky stream. It is kilometer from Iyengr, that is literally within. Big concern in us is caused that we have a drinking well there" (focus group, the village of Iyengr). According to the worker of municipal services, the expertize of water which is carried out by ecologists from a stream Volkovsky 
regarding compliance to the established standards showed that copper excess 24 time, gland of 40 times.

On November $32019 \mathrm{Mr}$. Iyengra residents of the village came to a meeting against placer gold mining by prospecting artel of "Titan-Avtotreyd" on a stream Volkovsky. However, the problem and remains unresolved.

In all areas of the conducted research respondents note growth of ecodependent diseases: "To oncology there was more as I think, all this because of ecology. All this is connected because of dirty water, food. We worry because of water. Water became very dirty. The most important - water. We drink water from the river" (the medic, the village of Koudou-Cuel).

As representatives of the people speak: "the Evenk without deer - not the Evenk". Preservation of reindeer breeding assumes existence of a connection: a pasture a deer - the reindeer breeder. The main condition is that the pasture should correspond to an oleneemkost. The Oleneemkost pays off the number of grazing days on hectare. A talk on a pasture rose every time, so far as concerned preservation of a livestock of deer. Chairmen of tribal communities suggest to bring the concept "olenepastbishche" in normative documents and to secure, thus, pastures against other encroachments. Constant wildfires reduce a food supply of deer. Sometimes respondents with regret say that they are forced to do this because of a shortage of a food supply, natural cataclysms, attacks of predators, paperwork, deterioration in the state of health. "We had deer. Over the last 5 years they died. There was a little, but were. Wolves destroyed them. Earlier my father grazed deer in thousands. It state farm worked. And now we try to live by the Evenki traditions, but it is bad that there are no deer. Now we hunting, gathering berries. Young people are engaged in national sewing" (the teacher, the village of Koudou-Cuel). Who managed to keep deer, continues to experience difficulties and tries to solve problems independently: "The food supply was reduced because of the fires. Now people have no deer, generally are engaged in hunting. It is impossible to approach them with deer. Their dogs to disperse deer. This biggest problem. Therefore I go by a snowmobile without deer" (the member of tribal community "Olyokma", he village of Koudou-Cuel).

Among consequences of impact of industrial projects on traditional environmental management respondents in all three districts call violation of migration of wild animals because of changes of a landscape, noise, deforestation. In South Yakutia the main subjects to hunting are wild hoofed animals (an elk, and a wild reindeer), fur trade (a sable, a fox, a hare), a waterfowl and upland fowl. According to the hunter of the village of Koudou-Cuel, even the road conducting from the village to the area can break migration of animals. If earlier there it was possible to hunt much, then now he did not find even traces of a hare and a sable. Where there go cars, animals do not come nearer. Violation of natural balance leads to change of traditional tenor of life of hunters and reindeer breeders.

Results of field researches indicate negative impact of industrial works in borders of territories of traditional environmental management and first of all, violation of an ecosystem. Environmental pollution leads to emergence of economic and social problems in rural territories: to reduction of pastures, decrease in the income of members of a communities, growth of unemployment and oncological diseases.

Authors conducted researches on studying of interaction of the industrial companies, tribal communities and local authorities in areas of observation. The analysis showed on emergence of mechanisms of interaction of sectors in territories of industrial development during preparatory work on the investment project. But it concerning, the large companies which are carrying out projects of federal and regional scale. These communications are formed when carrying out public hearings on environmental impact assessment of a designed project on the concrete territory. From this point, it is possible to tell there is an interaction between sectors to a stage of construction after which there is a self-elimination of the companies. During preparatory work of the investment project, the order and instruments of interaction with the industrial sector can form traditional and public sector. In all other stages of implementation of the investment project the industrial sector is doesn't develop connections on places of development.

The small mining enterprises in discharge from interaction with local community which concentrating the attention to interaction only with territorial authorities of supervising and fiscal services of federal level. By results of researches, it is found out that only the gold mining enterprise "Neryungri Metallic" has the cooperation agreement with the area. Implementation of projects, connected with extraction of hydrocarbonic raw materials and coal is carried out within agreements with the Government of the Republic of Sakha (Yakutia).

\section{Discussion}

For the northern people violation of a landscape and ecobalance in the nature is perceived as inadmissible. In their culture eco-saving traditions and customs are under construction on sympathy and to division of tyagost of extreme conditions of the North. In the research "Ecology and Culture" of Pavlov N. S., comes to a conclusion: "The traditional outlook promoted formation rational, corresponding to opportunities of preservation of natural balance to receptions and methods of hunting economy. All hunting grounds were divided between separate families, the neutral earth was not ... As placement of forces of hunters corresponded to a harvest of trade fauna on concrete sites, trade was carried out due to surplus of a game without violation of compliance to a food supply and without violation of gender and age structure ... Therefore it was possible to claim that ancient hunters collected not a God's not artificial gift, and to some extent fruits of own works and cares" [14]. The author's thought that "the harvest of trade culture" is result of fruits of own works and cares is very urgent at implementation of investment projects in the territory of 
traditional environmental management.

The concept of "the full world" is applicable to problems of indigenous people also those that "The North is a border, a limit of expansion of an industrial civilization, its last reserve" [10]. The North - an extreme boundary of situations of "the full world" when which filling the bowl of scales can quite will shake towards irreversible consequences. Feature of a northern country is that the speed of restoration of natural resources and the deposit of waste because of extreme climatic conditions goes with a slow speed, than in other regions of the world where the climate allows to restore damage caused to the nature quickly.

Almost uncontrolled, injurious production of resources - is the main contradiction between economic and welfare interests of three sectors of economy of northern settlements. In the monograph of group of authors "A resource damnation" and social examination in Post-Soviet Siberia: anthropological prospects" are generalized the Russian cases which are illustrated by social practicians of interaction of three sectors of economy of regions of resource type. Fight for resources, control and the competition for production of resources, material and diskursivny properties of resources became the subject field of the monograph. In this fight as winners as Earth for all one will not be at war.

In work of authors of Jiménez et al. the research of types of the conflicts between indigenous people and the industrial companies and their influence on water resources is given. The research showed that mining and hydropower infrastructure are most subject to the conflicts which cause the most essential changes in quality and availability of water to indigenous people [6]. In the areas explored by us, similar results were received. The main reason, the conflict is extraction of placer gold on places of drinking water of the population.

Within the Sakhalin consortium the Russian companies substantially rely on programs of corporate social responsibility and bring benefit to the communities which developed as a result of the Soviet and Post-Soviet practice in Russia in which the economic enterprises are concentrated on construction of social infrastructure and sponsorship. Untill 2012 financing was limited to the bilateral relations between the company and a community which then became tripartite under pressure from the state and indigenous people. A tripartite framework allowed to provide closer coordination at distribution of means among indigenous people [3].

\section{Conclusion}

Main objective of sustainable development on the primordial habitat of indigenous ethnic groups is protection of interests of the people living in this territory, decrease in technogenic load of the environment and development of economy for the purpose of improvement of quality of life of the population. At the existing mechanisms of state policy concerning large business as source of replenishment of the income and according to their support, leads to emergence of the acute social and economic issues connected with pollution of ecosystems, weak control from local authorities, reduction of grounds for traditional environmental management of indigenous people and many other factors.

Interaction of the industrial sector it is limited to time coordinated to phases of the investment project. Most often, coherence of three sectors occurs at a project design stage, however such relations can be defined as unstable or weak. In all other phases of the investment project the industrial companies create administrative barriers, aggravating the arising problems of ecological and social character in places of traditional environmental management.

With improvement of the legislation in the sphere of protection of indigenous ethnic groups loss of powers of regional and local authorities in the field of environmental management followed. In particular, in the sphere of land and resource legislations in which changes of legal regulation lead to an imbalance in territories of industrial development.

The model of three-sector development at implementation of investment projects defines the following basic principles:

- stability - establishes balance between sectors which is expressed in rational environmental management and environmental protection, preservation and development of a traditional way of life of indigenous ethnic groups, consolidations of society and the power;

- scientific validity - implementation of the investment project on on the territory of traditional nature management assumes the accounting of ecological, economic and social factors at design of the planned economic activity of the companies;

- the openness - consists in disclosure of the project documentation of the industrial sector, in particular the applied technologies of production and exploration works;

- systemacity - establishes connection of sectors (state, industrial and traditional) and complete approach on management steady development of the territory of industrial development.

The research of the investment projects existing the practician of realization in the places of residence of indigenous people causes formation of steady system at application of approaches of corporate social responsibility at realization investment projects in the places of residence and conducting traditional activity of indigenous people in which the responsibility for the environment and business to the community also prevails.

\section{Acknowledgement}

Article it is published at the expense of means of the state task 2.2 «Assessment of a state and a tendency of a social and economic condition of indigenous ethnic groups in the conditions of industrial development on the territory of the Republic of Sakha (Yakutia)» of 
Academy of Sciences of the Republic of Sakha (Yakutia).

\section{References}

1. H.E. Daly, R. Costanza, From a Failed Growth Economy to a Steady-State Economy, (In Encyclopedia of Earth. Eds. Cutler J. Cleveland, Washington, D.C.: Environmental Information Coalition, National Council for Science and the Environment, 5 June 2009).

2. H.E. Daly, Economics in a Full World, Economics Scientific American 293, 100-107 (September 2005). DOI: $10.1038 /$ scientificamerican0905-100.

3. M. Tysiachniouk, L.A. Henry, M. Lamers, Jan P.M. van Tatenhove, Oil and indigenous people in sub-Arctic Russia: Rethinking equity and governance in benefit sharing agreements, Energy Research \& Social Science 37, 140-152 (2018). DOI: https://doi.org/10.1016/j.erss.2017.09.004.

4. M. Prasad, T. Mishra, V. Bapat, Corporate social responsibility and environmental sustainability: Evidence from India using energy intensity as an indicator of environmental sustainability, Corporate social responsibility and environmental sustainability: Evidence from India using energy intensity as an indicator of environmental sustainability, IIMB Management Review 31, 374385 (2019).

5. E. Weizsaecker, A. Wijkman, Come On! Capitalism, Short-termism, Population and the Destruction of the Planet (Springer, 220, 2018).

6. And. Jiménez, M.F. Molina, H. Le Deunff, Indigenous Peoples and Industry Water Users: Mapping the Conflicts Worldwide, Aquatic $\begin{array}{llll}\text { Procedia 5, 69-80 (2015). DOI: } & \text { 5, }\end{array}$ https://doi.org/10.1016/j.aqpro.2015.10.009.

7. Tribal Nomadic Communities of Indigenous Ethnic Groups of the North of the Republic of Sakha (Yakutia) (database 2019622487).

8. S.M. Baisheva, Etnosotsialnaya adaptation of indigenous ethnic groups of the North of the Republic of Sakha (Yakutia) (Novosibirsk: Science, 363, 2012).

9. The state report on a state and environmental protection of $R S(Y a)$ in 2018 (Yakutsk, 2019).

10. A.P. Gudyma, Social and philosophical and ecological aspects of sustainable development of indigenous ethnic groups of Social-Philosophical and Ecological Aspects of the Sustainable Development of the Scanty Northern Peoples: anolyte (Novosibirsk, 109, 2002).

11. The concept of sustainable development of the Arctic uluses and places of compact accommodation of indigenous ethnic groups of the North of the Republic of Sakha (Yakutia) till 2020 Electronic resource., Yakutsk (2007). Available at: https://docviewer.yandex.ru/view/7964839.

12. Donella X.Medouz, et al., Growth limits. the lane with English (M.: MSU publishing house, 1991).
13. Monitoring of economic and social situation of city districts and municipal districts of RS (Ya) for January-December 2018, Yakutsk (2019).

14. N.S. Pavlova, Ecology and culture: studies a grant (Yakutsk: Publishing house of the Yakut university, 75, 1997).

15. I.M. Potravny, V.A. Gassy, S.M. Afanasyev, Territories of traditional environmental management: restrictions of development and factors of economic growth?, Arctic: ecology and economy 2, 26, 4-16 (2010).

16. D.A. Funk, V.V. Poddubikov, E.V. Miskova, al et., $A$ resource damnation and social examination in Post-Soviet Siberia: anthropological prospects (M.: LLC Demos Printing House, 312, 2019).

17. Statistical year-book of the Republic of Sakha (Yakutia), TO FSGS RS (Ya), Yakutsk, 852 (2018).

18. O.A. Murashko, Traditional knowledge, culture and environmental management of peoples of the North: annex to the almanac "Mir Korennykh Narodov-zhivaya Arktika" (M.: AKMHCC and DV Russian Federation, TsS KMNS of RITTS, 99, 2005).

19. The resolution of the government of $\mathrm{RS}(\mathrm{Ya})$ of 17.12.2007 No. 515 "About the concept of sustainable development of the Arctic uluses and places of compact accommodation of indigenous ethnic groups of the North of RS(Ya) till 2020" Electronic resource.. Available at: http://docs.cntd.ru/document/445037425.

20. Materials of the Northern forum on sustainable development, Yakutsk (24-28 September 2019) Electronic resource.. Available at: https://nsdf.ru. 